\title{
EFFECTS OF THE SCHROTH METHOD FOR TRUNK MUSCLES' STATIC ENDURANCE AND SPINE MOBILITY IN GIRLS WITH IDIOPATHIC SCOLIOSIS
}

\author{
Vaiva Strukčinskaitė ${ }^{1,2}$,Juozas Raistenskis ${ }^{1,2}$, Aurelija Šidlauskienè ${ }^{1,2}$, Birutė Strukčinskienė $\dot{3}^{3}$, \\ Sigitas Griškonis ${ }^{3,4}$ \\ ${ }^{1}$ Faculty of Medicine, Vilnius University, ${ }^{2}$ Children's Hospital, Affiliate of Vilnius University \\ Hospital Santaros Klinikos, Physical Medicine and Rehabilitation Centre, \\ ${ }^{3}$ Faculty of Health Sciences, Klaipeda University, ${ }^{4}$ Klaipeda University Hospital, Lithuania
}

Key words: Schroth, idiopathic scoliosis, girls, physiotherapy, static endurance, spine mobility.

\section{Summary}

The prevalence of scoliosis in the paediatric population is increasing every year. The treatment of idiopathic scoliosis in Lithuania is based on traditional physical therapy, and it is not always the most effective. Schroth method recently is widely globally used evidence-based conservative scoliosis treatment method. The aim of the study was to assess the effects of the Schroth method treatment for trunk muscles' static endurance and spine mobility in girls with idiopathic scoliosis. The study was conducted in 2016-2017 at the Physical Medicine and Rehabilitation Centre, Children's Hospital, Affiliate of Vilnius University Hospital Santaros Klinikos. In the study participated 50 girls aged 9-17 years with idiopathic scoliosis. The patients were divided into two groups: the study group $(n=25)$ and the control group $(n=$ 25). Schroth treatment method for the study group and a traditional physiotherapy for the control group were used. For patients were applied 10 procedures of physiotherapy (for 30 minutes, 5 times a week). The study showed that trunk muscles' static endurance results after rehabilitation were significantly higher in the study group than in the control group $(\mathrm{p}<0.05)$. The analysis of the average changes in the results between the groups revealed that in the study group the results of abdominal muscles (16.08 s more), left side trunk muscles (6.98 s more), and right side trunk muscles ( $7.84 \mathrm{~s}$ more) had changed significantly. Results of spine mobility significantly improved in both groups after rehabilitation $(\mathrm{p}<0.05)$. Trunk flexion amplitude estimated to have significantly greater improvement in the study group. The treatment using Schroth method had significantly improved the indicators of trunk muscles' static endurance and mobility of the spine during spinal flexion. When compare the results inside the groups, the significant change was shown in the majority of spine and posture-related parameters in the study group. Special physiotherapy, especially Schroth method for children with idiopathic scoliosis have been shown to be an effective conservative treatment for scoliosis.

\section{Introduction}

The International Scientific Society on Scoliosis Orthopaedic and Rehabilitation Treatment (SOSORT) has provided a definition of scoliosis, that it is a spinal curvature in the frontal plane of more than 10 degrees Cobb angle with vertebrae rotation. Scoliosis is three-dimensional (3D) spinal deformity pathology. The SOSORT guidelines state that only $20 \%$ scoliosis has known aetiology. Mainly scoliosis $(80 \%)$ occur as idiopathic scoliosis of unknown origin. According to SOSORT, the incidence of adolescent idiopathic scoliosis ranges from $0.93 \%$ to $12 \%$, most often $2-3 \%$ [1]. The ratio of adolescents' idiopathic scoliosis in girls and boys ranges from 1.5: 1 to 3: 1 and increases with age. Girls' degree of scoliosis tends to be greater than that of boys [2]. According to the Health Information Centre of the Lithuanian Hygiene Institute, the number of cases of scoliosis and flatfoot in Lithuania is increasing every year [3]. The prevalence of scoliosis in the paediatric population is increasing every year. The treatment of idiopathic scoliosis in Lithuania is based on traditional physical therapy and is not always effective.

According to the latest recommendations of SOSORT, idiopathic scoliosis treatment depends on degrees of spinal 
deviation; when the curve is $10^{\circ}-25^{\circ}$, it is treated with specific physiotherapy, in case of $25^{\circ}-50^{\circ}$ - it is treated with spinal brace support and specific physiotherapy, and when the curve is more than $50^{\circ}$, the treatment involves surgery [4].

Specific physiotherapy is method of physiotherapy designed specifically for patients with scoliosis diagnosis. Specific physiotherapy is based on treatment for individual patient with focus on scoliosis curvature (degree, type), and using specific physiotherapy techniques. Specific physiotherapy for the treatment of scoliosis should include three-dimensional posture autocorrecting, corrected postural stabilization, patient training, and corrective treatment in everyday life [5]. Schroth method recently is widely globally used evidence-based conservative scoliosis treatment method [4]. This is a three-dimensional scoliosis treatment. The essence of Schroth's method is the "hypercorrection" of the spine. It is the application of certain positions opposite to the natural curves and the reinforcement of hypercorrection obtained through the special exercises [6].

Spine mobility of the scoliosis patient is less flexible and this is associated with a thoracolumbar fascia $[7,8]$. In addition, there are the changes of trunk muscle balance in both functional and anatomical parameters $[9,10]$. Electromyography measurements show different strengths of electrical signals in the both sides of scoliotic spine [11,12]. The objectives of the study were to determine the static endurance of trunk muscles and spine mobility of the subjects before and after rehabilitation; to compare the treatment effectiveness between Schroth method and traditional physiotherapy treatment.

Table 1. Static trunk muscles' static endurance

\begin{tabular}{|l|l|l|l|l|l|}
\hline \multicolumn{2}{|c|}{} & \multicolumn{5}{|l|}{ Trunk muscles' static endurance mean $( \pm$ SD $)(\mathrm{s})$} \\
\cline { 3 - 7 } \multicolumn{2}{|c|}{} & Abdominal & Back & Left side & Right side \\
\hline \multirow{2}{*}{$\begin{array}{l}\text { gtudy } \\
\text { group }\end{array}$} & Before rehabilitation & $42.72 \pm 22.80$ & $63.28 \pm 39.22$ & $32.08 \pm 18.69$ & $32.44 \pm 20.23$ \\
\cline { 2 - 7 } & After rehabilitation & $71.24 \pm 37.03$ & $86.64 \pm 39.25$ & $43.28 \pm 21.11$ & $45.24 \pm 20.39$ \\
\cline { 2 - 7 } & Mean change & 28,$52 ; \mathbf{p}=\mathbf{0 . 0 0 0}$ & $23.36 ; \mathbf{p}=\mathbf{0 . 0 0 0}$ & $11.2 ; \mathbf{p}=\mathbf{0 . 0 0 0}$ & $12.8 ; \mathbf{p}=\mathbf{0 . 0 0 0}$ \\
\hline \multirow{2}{*}{$\begin{array}{l}\text { Gontrol } \\
\text { group }\end{array}$} & Before rehabilitation & $36.8 \pm 16.65$ & $53.04 \pm 26.03$ & $26.72 \pm 16.09$ & $27.04 \pm 15.78$ \\
\cline { 2 - 7 } & After rehabilitation & $49.24 \pm 20.27$ & $64.16 \pm 25.05$ & $31 \pm 16.60$ & $32 \pm 26.86$ \\
\cline { 2 - 7 } $\begin{array}{l}\text { Results difference between } \\
\text { groups }\end{array}$ & $12.44 ; \mathbf{p}=\mathbf{0 . 0 0 0}$ & $11.12 ; \mathbf{p}=\mathbf{0 . 0 0 0}$ & $4.28 ; \mathbf{p}=\mathbf{0 . 0 0 0}$ & $4.96 ; \mathbf{p}=\mathbf{0 . 0 0 0}$ \\
\hline
\end{tabular}

Table 2. Static trunk muscles' endurance ratios

\begin{tabular}{|l|c|c|c|c|c|c|c|}
\hline \multirow{2}{*}{$\begin{array}{l}\text { Results propor- } \\
\text { tion }\end{array}$} & \multicolumn{3}{|c|}{ Study group } & \multicolumn{3}{c|}{ Control group } & \multirow{2}{*}{$\begin{array}{c}\text { p, comparison of } \\
\text { both group results }\end{array}$} \\
\cline { 2 - 9 } & Before & After & Difference & Before & After & Difference & 0.114 \\
\hline Abs-back & 1.32 & 1.98 & 0.66 & 1.68 & 1.31 & -0.37 & 0.977 \\
\hline Left side-back & 1.56 & 1.51 & -0.05 & 1.55 & 1.25 & -0.3 & 0.607 \\
\hline Right side-back & 1.51 & 1.56 & 0.05 & 1.28 & 1.07 & -0.21 & 0.184 \\
\hline Left-right sides & 1.10 & 0.95 & -0.15 & 2.00 & 1.85 & -0.15 & \\
\hline
\end{tabular}

The aim of the study was to assess the effects of the Schroth method for static muscle endurance and spine mobility in girls who have idiopathic scoliosis

\section{Materials and Methods}

The study was conducted in 2016-2017 at the Centre of Physical Medicine and Rehabilitation, Children's Hospital, Affiliate of Vilnius University Hospital Santaros Klinikos. In the study participated 50 girls aged 9-17 years with idiopathic scoliosis. The patients were divided into two groups: the study group $(n=25)$ and the control group $(n=25)$. Schroth treatment method for the study group and a traditional physiotherapy for the control group were used. For patients were applied 10 procedures of physiotherapy (for 30 minutes, 5 times a week). Trunk muscles static endurance and spine mobility tests were applied. SPSS 21.0 and MS Excel were used for statistical analysis.

\section{Results and Discussion}

During the study, we analyzed trunk muscles static endurance and spine mobility parameters' changes after rehabilitation using usual physiotherapy and physiotherapy according to Schroth method for girls with idiopathic scoliosis.

In both study and control groups, the results of trunk muscles' static endurance were statistically significantly higher after than before rehabilitation. Trunk muscles' static endurance testing results in both groups, before and after physiotherapy are shown in Table 1 . The study showed that in the study group, the results of endurance of the abdominal muscles increased by $28.52 \mathrm{~s}$, of the back muscles -23.36 $\mathrm{s}$, of the muscles of the left side of the trunk - $11.2 \mathrm{~s}$, and of the right side muscles $12.8 \mathrm{~s}(\mathrm{p}=0.000)$. In the control group, the results of endurance of the abdominal muscles increased by 12.44 $\mathrm{s}$, of the back muscles $11.12 \mathrm{~s}$, of the muscles of the left side of trunk -4.28 $\mathrm{s}$, and of the right side muscles $-4.96 \mathrm{~s}(\mathrm{p}=0.000)$.

We compared the results after rehabilitation between study and control groups. The study revealed that the results of trunk muscles' static endurance after rehabilitation were significantly higher in the study group than in the control group $(p<0.05)$. When compare 
the results between study and control groups after rehabilitation, it was shown that the results of the study group were better than results of the control group. In the study group, abdominal muscles' endurance was $22 \mathrm{~s}$ greater ( $\mathrm{p}$ $=0.014)$, back muscles' endurance was $22.48 \mathrm{~s}$ greater $(\mathrm{p}=$ $0.017)$, left side of the trunk muscles' endurance was 12.28 $\mathrm{s}$ greater $(\mathrm{p}=0.036)$, and the right side of trunk muscles' endurance was $13.24 \mathrm{~s}$ greater $(\mathrm{p}=0.011)$ than the results of the control group.

The results of the mean changes of the abdominal muscles and right and left side trunk muscles' were significantly

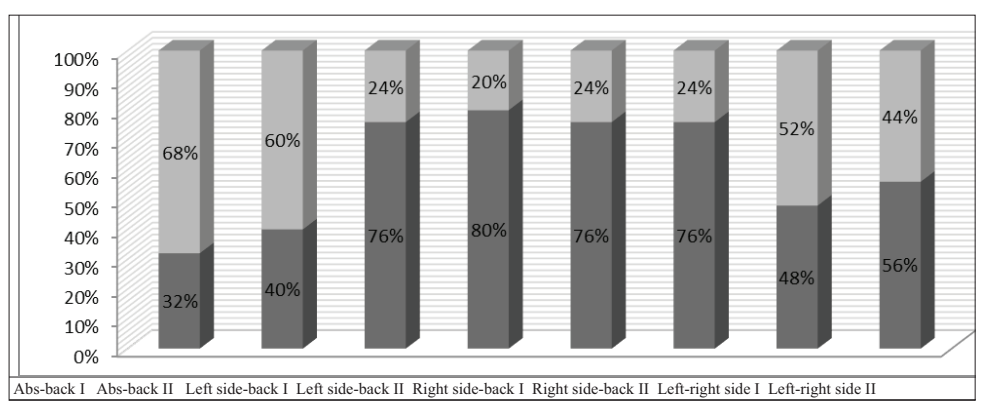

Figure 1. Trunk muscles' static endurance ratios in the study group

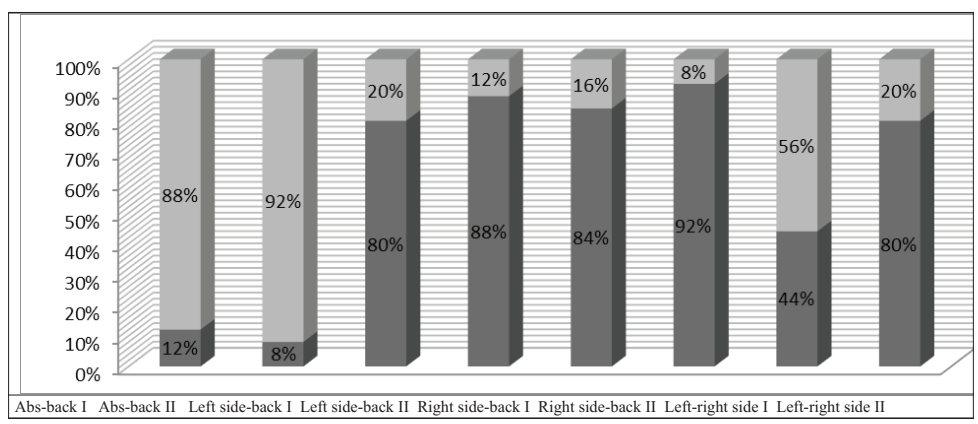

Figure 2. Trunk muscles' static endurance ratios in the control group

\begin{tabular}{|c|c|c|c|c|}
\hline \multirow{5}{*}{ 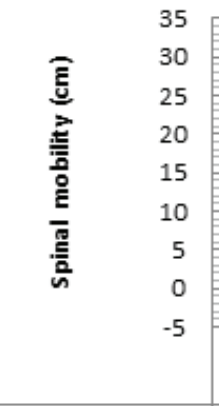 } & \multicolumn{4}{|c|}{$\mathrm{T}$} \\
\hline & \multicolumn{4}{|c|}{1} \\
\hline & & 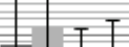 & $1=$ & 11 \\
\hline & & 11 & & \\
\hline & Flexion & Extension & $\begin{array}{c}\text { Lateral } \\
\text { flexion left }\end{array}$ & $\begin{array}{c}\text { Lateral } \\
\text { flexion right }\end{array}$ \\
\hline E Study group I & 3.04 & 13.72 & 20.76 & 20.6 \\
\hline Wtudy group II & 1.32 & 15.76 & 22 & 22.16 \\
\hline Control group I & 8.64 & 11.32 & 17.04 & 17.76 \\
\hline Control group II & 5.88 & 12.76 & 18.68 & 19.32 \\
\hline
\end{tabular}

Figure 3. Spinal mobility before and after rehabilitation higher in the study group than in the control group. The mean change of the abdominal muscles' results was 16.08 s greater $(p=0.002)$, in right side of trunk muscles' results was $7.84 \mathrm{~s}$ greater $(\mathrm{p}=0.001)$, and the change of the results in the left side of the trunk muscles' was $6.98 \mathrm{~s}(\mathrm{p}=0.015)$, and statistically significantly higher than in the study group (Table 1).

When compare the trunk muscles' static endurance results of both sides of trunk, no significant differences between the study and the control group, both before and after rehabilitation were observed $(p>0.05)$. The results of abdominal and back muscles' static endurance were analyzed in accordance with McGill (2002) [13]; the results were interpreted as follows: $20-30 \mathrm{~s}$ as a norm, $15-20 \mathrm{~s}$ as good, $10-15 \mathrm{~s}$ as middle, and $1-10 \mathrm{~s}$ as weak.

During study, trunk muscles' static endurance results analysis was made according to the results' rations of the different muscles groups. The abdominal and back muscles results' ratios considered as norm when ratio is $\geq 1.0$. Left or right side of the trunk muscles results' ratio with back muscles should be less than 0.75 . Left and right side of the trunk muscles' static endurance results ratio is considered as norm when ratio is 1. Normally, muscles' static endurance of the one side is higher than of the other side, depending on the prevailing arm [13]. Trunk muscles' static endurance results ratios are shown in the Table 2 . The ratios between the results of abdominal and back muscles' endurance were significantly better in the study group than in the control group.

Trunk muscles' endurance results' ratios norms are shown in Figure 1 and Figure 2.

The study group results are shown in the Figure 1 . Before physiotherapy $32 \%$ and after physiotherapy $40 \%$ of patients reached norm of abdominal and back muscles' ratio. Before physiotherapy $76 \%$ and $80 \%$ after physiotherapy of patients showed norm in trunk left side and back muscles' ratio. The ratio of trunk right side and back muscles' static endurance was in accordance to norm in $76 \%$ of the patient before and after physiotherapy. Left - right side trunk muscles' ratio reached norm in $48 \%$ patients before and $56 \%$ after physiotherapy. The number of patients who reached norm was increasing in abdominalback, left side-back and left-right side of the trunk muscles' endurance results ratios after physiotherapy (Figure 1).

The control group results are shown in the Figure 2. Before physiotherapy $12 \%$ and after 
physiotherapy only $8 \%$ of the girls reached norm of abdominal and back muscles' ratio. $80 \%$ before physiotherapy and $88 \%$ after physiotherapy of the patients had trunk left side and back muscles ratio in accordance to the norm. The trunk right side and back muscles' static endurance ratio was in norm in $84 \%$ patients before and $92 \%$ patients after physiotherapy. Left - right trunk muscles ratio reached norm in $44 \%$ patients before and $80 \%$ after the physiotherapy.

The number of patients with lift side-back and right sideback ration as norm had increased after the rehabilitation and in the number of patients with left-right side ratio as a norm a two-fold increased was observed.

When analyzing the trunk muscles' static endurance ratios after rehabilitation among the groups, it was found that the abdominal - back muscles' ratios were significantly higher in the study group girls $(\mathrm{p}=0.008)$.

During the study, spine mobility parameters were measured: spinal flexion, extension, and lateral flexion to the left and right side. Spinal flexion was measured by finger-to-floor distance. Results of spine mobility significantly improved in both groups after rehabilitation $(\mathrm{p}<0.05)$ (Figure 3 ).

Trunk flexion amplitude estimated to have significantly greater improvement in the study group. Before physiotherapy $12(48 \%)$ girls in the study group and $6(24 \%)$ girls in the control group reached the floor and had $0 \mathrm{~cm}$ finger-tofloor distance. $19(76 \%)$ girls in the study group and $9(36 \%)$ in the girl control group had $0 \mathrm{~cm}$ finger-to-floor distance result after physiotherapy.

When analyzing the differences between lateral trunk flexion to the left and right side there was no statistically significant differences in the results of both, the study ( $p=$ $0.682)$ and control $(p=0.273)$ groups before physiotherapy. When evaluating the results of bending to different sides after physiotherapy, it was found that there were no statistically significant differences between groups $(\mathrm{p}=0.527)$. After rehabilitation in the study group, the results of the left side bending showed a tendency to be higher than the control group $(\mathrm{p}=0.073)$.

The results of the trunk muscles' static endurance and spine mobility in the study and control groups after the rehabilitation significantly improved. The use of the special physiotherapy in the treatment of scoliosis requires strengthening paraspinal and trunk muscles. It has been shown by scientific studies that in the case of scoliosis, degenerative changes in both sides of scoliotic spine. are observed (signs of myopathy, muscle atrophy, and fibrotic, and necrotizing tissue changes) [14]. In a study conducted in Turkey, the Cobb angle, lung capacity and trunk muscles' strength were significantly improved in the study group after physiotherapy [15]. In our study, when compare the results between groups after rehabilitation, it was found that in the study group, the results of the trunk muscles' static endurance were significantly higher than in the control group. When analyzing the mean changes in results between two groups, the results of the abdominal muscles ( $16.08 \mathrm{~s}$ more), of the left-side ( 6.98 $\mathrm{s}$ more) and of the right-side ( $7.84 \mathrm{~s}$ more) muscles were significantly higher in the study group. Weiss et al. stated that using a special physiotherapy, the Schroth method helps to achieve significant improvement in trunk muscles balance [5]. When analyzing the results' ratios of the trunk muscles' static endurance, it was found that the ratios of abdominal - back muscles ratios were significantly higher in the study group than in the control group.

In patients with scoliosis, it is important to maintain the flexibility of the spinal mobility, because the scoliosis curve may be loose or rigid, and it is difficult to achieve positive rehabilitation results in a rigid curve [6]. In this study, the results of the spine mobility in the study and control groups after the rehabilitation were significantly improved. When compare the spine mobility between the two groups, it was found that trunk flexion significantly improved in the study group. The paraspinal muscles' flexibility was according to the norm in all patients, who participated in the study.

It is recommended that for patients with scoliosis more procedures of physical therapy should be given. These procedures should be more intensive and last for longer period. Patients with scoliosis are advised to be physically active. Attention should be paid when choosing a type of physical activity, in order to prevent spinal asymmetries from being adversely affected. In addition, for patients with scoliosis it is recommended to keep corrective posture, correct body position, and correct breathing principles throughout the day.

\section{Conclusions}

1. The results of trunk muscles' static endurance in both study and control groups had significantly improved after the rehabilitation. The results of the static endurance of the trunk muscles after the rehabilitation were significantly higher in the study group than in the control group.

2. The results of spinal mobility in both study and control groups significantly improved after the rehabilitation. When compare spinal mobility between the study and control groups, it was shown that spinal flexion significantly improved in the study group.

3. The use of the Schroth method had significantly improved the parameters of trunk muscles' static endurance and spinal mobility during spine flexion.

\section{References}

1. Negrini S, Aulisa AG, Aulisa L, Circo AB, Mauroy JC, Durmala J. et al. 2011 SOSORT guidelines: orthopaedic and rehabilitation treatment of idiopathic scoliosis during growth. Scoliosis 2012; 7(1): 3 . 
https://doi.org/10.1186/1748-7161-7-3

2. Konieczny MR, Senyurt H, Krauspe R. Epidemiology of adolescent idiopathic scoliosis. Journal of Children's Orthopaedics 2013; 7(1): 3-9.

https://doi.org/10.1007/s11832-012-0457-4

3. Lietuvos gyventojų sveikata ir sveikatos priežiūros įstaigų veikla 2013 m. Vilnius: Higienos instituto Sveikatos informacijos centras, 2014.

4. Negrini S, Hresko TM, O'Brien JP, Price N, SRS Non-Operative Committee. Recommendations for research studies on treatment of idiopathic scoliosis: Consensus 2014 between SOSORT and SRS non-operative management committee. Scoliosis, 2015; 10: 8.

https://doi.org/10.1186/s13013-014-0025-4

5. Weiss HR. Schroth therapy: advancements in conservative scoliosis treatment. Saarbruecken: LAP Lambert Academic Publishing, 2015.

6. Fusco C, Zaina F, Atanasio S, Romano M, Negrini A, Negrini $\mathrm{S}$. Physical exercises in the treatment of adolescent idiopathic scoliosis: an updated systematic review. Physiotherapy theory and practice $2011 ; 27(1): 80-114$.

https://doi.org/10.3109/09593985.2010.533342

7. Adomaitienė I., Sinkevičius R., Stašienė E., Samuilis A., Raistenskis J., Strukčinskaitė, V. Torakaliumbalinès fascijos pakitimų vertinimas ultragarso tyrimo pagalba esant paauglių idiopatinei skoliozei - bandomasis tyrimas. Sveikatos mokslai, 2016; 26(2): 72-77.

https://doi.org/10.5200/sm-hs.2016.030

8. Langevin HM, Fox JR, Koptiuch C, Badger GJ, GreenanNaumann AC, Bouffard N. A. et al. Reduced thoracolumbar fascia shear strain in human chronic low back pain. BMC musculoskeletal disorders, 2011;12(1): 1 .

https://doi.org/10.1186/1471-2474-12-203

9. Zapata KA, Wang-Price SS, Sucato DJ, Dempsey-Robertson M. Ultrasonographic measurements of paraspinal muscle thickness in adolescent idiopathic scoliosis: a comparison and reliability study. Pediatric Physical Therapy 2015; 27(2): 119-125.

https://doi.org/10.1097/PEP.0000000000000131

10. Linek P, Saulicz E, Kuszewski M, Wolny T. Ultrasound assessment of the abdominal muscles at rest and during the ASLR test among adolescents with scoliosis. Clinical Spine Surgery 2017; 30(4): 181-186.

11. Nosko M, Razumeyko N, Lermakov S, Yermakova T. Correction of 6 to 10 -year-old schoolchildren postures using muscular-tonic imbalance indicators. Journal of Physical Education and Sport 2016; 16(3): 988-999.

12. Vives MJ. The paraspinal muscles and their role in the maintenance of global spinal alignment. Another wrinkle in an already complex problem. The Spine Journal 2016; 16(4): 459-461. https://doi.org/10.1016/j.spinee.2015.11.029

13. McGill S. Low Back Disorders. Evidence - Based Prevention and Rehabilitation. Champaign, IL: Human Kinetics, 2002.
14. Wajchenberg M, Luciano RP, Martins DE, Rodrigues LMR, Puertas EB, Cohen M. et al. Histological paraspinal muscle comparison between curve concavity and convexity in adolescent idiopathic scoliosis. Scoliosis, 2014; 9(1): O12.

https://doi.org/10.1186/1748-7161-9-S1-O12

15. Otman S, Kose N, Yakut Y. The efficacy of Schroth's 3-dimensional exercise therapy in the treatment of adolescent idiopathic scoliosis in Turkey. Saudi Medical Journal 2005; 26: 1429-1435.

\section{SCHROTH METODO POVEIKIS STATINEI LIEMENS RAUMENŲ IŠTVERMEI IR STUBURO LANKSTUMUI GYDANT MERGAITES, SERGANČIAS IDIOPATINE SKOLIOZE}

V. Strukčinskaitė, J. Raistenskis, A. Šidlauskienė, B. Strukčinskienė, S. Griškonis

Raktažodžiai: Schroth, idiopatinė skoliozè, mergaitės, kineziterapija, statinè ištvermè, stuburo lankstumas.

Santrauka

Skoliozès paplitimas vaikų populiacijoje kasmet dideja. Vienas naujausių ir labiausiai moksliškai pagrịstų specifinès kineziterapijos metodų - Schroth skoliozès gydymo metodika. Darbo tikslas buvo įvertinti Schroth metodo poveikị statinei liemens raumenų ištvermei ir stuburo lankstumui gydant mergaites, sergančias idiopatine skolioze. Darbo uždaviniai: ịvertinti tiriamujų statinę liemens raumenų ištvermę prieš ir po reabilitacijos, nustatyti tiriamujų stuburo paslankumą prieš ir po reabilitacijos, palyginti Schroth gydymo metodo ir tradicinès kineziterapijos efektyvumą. Tyrimas atliktas 2016 - 2017 m. Vaikų ligoninès, VšI Vilniaus universiteto ligoninès Santaros klinikų filialo, Vaikų fizinès medicinos ir reabilitacijos centre. Tyrime dalyvavo $50(n=50)$ 9-17 metų amžiaus mergaičių, sergančių idiopatine skolioze. Tiriamosios buvo suskirstytos ị dvi grupes: tiriamają $(n=25)$ ir kontrolinę $(n=25)$. Tiriamajai grupei taikyta kineziterapija pagal Schroth gydymo metodą, kontrolinei grupei - tradicine kineziterapija. Tyrimo metu abiejų grupių pacientėms buvo atlikta 10 kineziterapijos procedūrų, 5 kartus per savaitę po 30 minučių. Tiriamųjų vertinimui naudoti: liemens raumenų statinès ištvermès ir stuburo paslankumo vertinimo testai. Testavimai atlikti prieš ir po reabilitacijos. Statistinei duomenų analizei buvo naudoti SPSS 21.0 paketas ir „MS Excel“ programa. Duomenys vertinami kaip statistiškai reikšmingi, kai $\mathrm{p}<0,05$. Statinès liemens raumenų ištvermès rezultatai tiriamojoje ir kontrolinėje grupėse po reabilitacijos statistiškai reikšmingai gerejo, $\mathrm{p}<0,05$. Statinès liemens raumenų ištvermès rezultatai po reabilitacijos buvo reikšmingai geresni tiriamojoje nei kontrolinejje grupejje. Stuburo paslankumo rezultatai tiriamojoje ir kontrolinèje grupèse po reabilitacijos statistiškai reikšmingai gerèjo, $p<0,05$. Vertinant stuburo paslankumą tarp grupių, statistiškai reikšmingai labiau pagerejo tiriamosios grupès liemens fleksijos ịvertis. Schroth metodo taikymas statistiškai reikšmingai pagerino liemens raumenų statinès ištvermès rodiklius ir stuburo paslankumą atliekant stuburo fleksiją.

Adresas susirašinèti: vaiva.struk@gmail.com

Gauta 2017-11-06 